\title{
Instantial transformation of phraseological units as complex phenomenon
}

\author{
Elena Y. Semushina
}

DOI: 10.18355/XL.2019.12.03.13

\begin{abstract}
The paper focuses on the study of phraseological units of the English and Russian languages, which gives an opportunity to understand cultural life of people, development of the language and culture in general. The reasons for instantial (occasional) changes of the units are revealed, the ways of formation as well. The main types of interaction of certain types of instantial (occasional) phraseological units are defined. The transformations are classified according to the type of structural change, intention of the author, and semantics of the unit. The study of complex cases of transformation of phraseological units are of particular importance as it is the use of a combination of transformations that allows creating the necessary aesthetic effect. The following ways of contextual transformation of phraseological units are examined: substitution, ellipsis (allusion), saturation of context, repetition, cleft use, extended metaphor, expansion. The ways they interact in the discourse with a purpose of creating a complex case of transformation are analyzed. The works of English and Russian writers of the 20th and 21 st centuries were subjected to processing. The aspects of meaning that were changed according to a certain type of complex transformation are revealed.
\end{abstract}

Key words: inslantial use, complex transformation, substitution, allusion, cleft use, extended metaphor

\section{Introduction}

When creating a certain linguistic context, the author may face a situation when the unit available in the language does not meet the requirements of the native speaker, which leads to the use of occasional (instantial) transformations, including changes in both semantics and structure of the linguistic unit. At the present stage of development of comparative linguistics a complex character of phraseological transformation in the discourse is stated by the majority of linguists, however, there is a significant lack of the systematic analysis of compatibility of cases of instantial phraseological units forming a certain occasional phraseological discourse. As a result, the systematization of variants of discourse saturation comes forward.

A. Naciscione describes discourse analysis as the study of linguistic regularities and irregularities in segments of speech consisting of more than one sentence. Phraseological units can be used in two forms - core and instantial. Core use means that the unit is used in its basic form in the text. Instantial use occurs in speech and depends on relationship of lexical units inside the unit or with other words (Naciscione, 2001).

V. Telia claims that the implementation of instantial phraseological units can be perceived as an error of speech, if the speaker does not change the unit deliberately, being unaware of its figurative meaning (Telia, 1996). Transformations of phraseological units act as logical means of conceptual mechanism of the creative use of the language, and the necessity of the instantial use of the unit is based on the fact that the unit available in the language is not able to perform specialized language function which is required in the discourse (Arsent'eva, 2003). As a result, semantics and structure of the basic unit is changed (additional aspects of meaning, intensifying

XLinguae, Volume 12, Issue 3, June 2019, ISSN 1337-8384, eISSN 2453-711X 
expressive aspect, etc.). A week connection between the components of phraseological units is a prerequisite for the transformation in the discourse.

Instantial phraseological units are characterized by the following characteristics: individual and functional accessory; single use, novelty, expressiveness, ability to change. The change can takes place on semantic, lexical, morphological, stylistic and syntactic levels. Modification of semantics may lead to adding new indications, concrete definition of the basic meaning, changes of connotative aspect of the meaning (Bershadskaya, 1972).

The main types of instantial use of FU are the following: extended metaphor, pun, cleft use, allusion, repetition, phraseological saturation, substitution (Naciscione, 2001). When analyzing the functioning of units, a special role is played by the analysis of not only the unit itself, but also the discourse, as well as ways of interaction of these phenomena. The discourse actualizes the component of meaning which is changed according to the intention of the author.

The conversion potential of a phraseological unit is determined by three factors: syntax, semantics and pragmatics. Syntax and semantics depend on the structure of the language and interconnection of phraseological components, pragmatics is determined by the situation, motives and aims of the speaker. In other words, instantial changes of the unit obey certain rules. Besides, in most cases, transformation of phraseological units has a complex character.

The inner form of the unit is one of the main factors that influence the change of the unit, because mechanisms of forming new unit are based on cognitive basis (Kalenova, 2011).

\section{Results}

\section{Extended metaphor}

Extended metaphor is a type of instantial transformation of a unit that is based on the creation of additional metaphorical elements, each of which is based on the use of the basic unit. In fact, the extended metaphor is a complex case of instantial transformation of linguistic units with actualization of connotative as well as denotative component of meaning. Extended phraseological metaphor has the following ways of formation, depending on the form of the initial phraseological unit:

a) Formation of extended metaphors is based on the stable basic form of phraseological unit. For example, the phraseological unit "a heavy heart" forms extended metaphor with the help of postpositive expansion and actualizer "to lighten" in English:

She woke on the morning appointed for her initiation into the Shadow Scheme with a heavy heart, which the weather did nothing to lighten. (Lodge, 1989)

The use of a post-positive expansion leads to creation of an extended metaphor in the following example in the Russian languge:

Все мы ждем принца на белом коне, но в случае Кузиной жеребец прискакал один (Dontsova, 2005).

b) Formation of extended metaphors is based on the basic form of phraseological unit, which has been transformed previously. For example, phraseological unit "two-faced Janys" is used in a truncated form with explanation that makes the use of extended metaphor reasonable:

I'm not one with two faces-one for my master, and t'other for his back (Gaskel, 1994).

Phraseological unit «чужая душа - потемки» is used as a basis of extended metaphor, having been truncated before:

Неясно, что там было дальше ...Время все съело. Добавим к этому, что читать в чужсой душе трудно: темно, и дано не всякому. Смутные домыслы, попытки догадок - не больше (Tolstaa, 2004). 
The extended phraseological metaphor as a case of complex transformation is formed in most cases, based on different types of repetition, in combination with other variants of contextual realization that will be examined further.

\section{Substitution}

Instantial substitution in the discourse is possible because of dual character of the meaning of the phraseological unit. The meaning of a new component is introduced into the general meaning, modifying it. That is why a type of a new component depends on the meaning of it, the discourse itself, extra linguistic realities as well as the basic meaning of the unit. Intantial substitution easily takes place if the bond between the components is week, the fact that can be confirmed by the existence of basic variants of the unit in the dictionary.

Substitution leads to significant change of meaning of the unit as well as adding new element of meaning, for example, modification of subjective attitude of the author. Based on the type of the component, the new one can be a synonym, neologism, neutral component, antonym, etc. (Telia, 1996).

Analyzing the final (general) meaning of substituted units in the Russian and English languages, the following types of instantial units are defined:

1) Synonymous type - the synonym of the basic unit is formed as a result. The following subtypes can be defined here in both languages:

a) New components (substitutes) are the synonyms of the basic ones or are close to the meaning of the basic component. As a result, slight modification of meaning takes place (intensification). For example, substitution of the second component in the phraseological unit «ловить рыбку в мутной воде» is caused by the fact that the main character intents to get a lot of money.

... Зелимхан оказался среди немногих граждан, которые хорошо поняли: настало время ловить кита в мутной воде (Dontsova, 2005).

Substitution of the first component in the unit "a self-made man" leads to additional shade of meaning "faithful".

I should say that this Morison is no true man. I don't know who he is, I merely judge him from your account. I suspect my gentleman includes your true man (Gaskel, 1994).

In both languages, similarities in the process of selecting a new component are observed. For example, substitution of the first component in a phraseological unit «длинный язык» to component «ядовитый» in the Russian language and substitution of the first component in the unit "long tongue" to "bitter" in the English language.

It wouldn't be a very good marriage for her, but it was a marriage, and the fact that she would live in China made it easier. She was afraid of her mother's bitter tongue. (Maugham, 2004)

Ну! С таким ядовитым языком теща из тебя славная выйдет. (Иванов, 1999)

b) New component is the antonym of the basic one, but the final (general) denotative meaning is not changed, semantic modification of connotative component is observed. For example, after substitution of the first component in the unit «бандит с большой дороги», negative attitude to a person is preserved, but additional elements of meaning can be found «friendship» and «betrayal»:

... мой добрый приятель, милый человек, отличный врач, великолепный психиатр. Одним словом, друг с большой дороги. (Dontsova, 2005)

2) Antonymous type of substitution - the antonym of the basic unit is formed. It should be mentioned that to form a new phraseological unit an arbitrary component, not always the antonym of the basic one, could be used. For example, substitution of the first component in phraseological unit "big heart" leads to formation of a new phraseological unit which means "cruelty".

XLinguae, Volume 12, Issue 3, June 2019, ISSN 1337-8384, eISSN 2453-711X 
I know that he disliked my own dear boy. I think it a certain proof he had a bad heart. (Gaskel, 1994)

A partial change of the syntactic model leads to the formation of an instantial proverb with the opposite meaning in the Russian language that is complex transformation.

Мой «Ниро Вульф» в своем репертуаре! Не желает никого слушать. Элеоноре принадлежит гениальное высказывание: "Одна голова хорошо, а вторая пошла вон со своими советами». (Дониова, 2007) - The basic proverb is «Одна голова хорошо, а две лучше».

Substitution of a component can be the basis for creating a complex type of transformation when it is combined with saturation of the discourse with a number of units that have undergone substitution as well:

Тридиатишестилетняя Кло Катиенбах, шеф отдела валютных операчий иэюрихского «Ситизен-банка» родилась, по мнению многих людей .... в вышитой

ночной сорочке, с бриллиантовой подвеской в ухе и с целым клоком белых волос редкой счастливицы. (Mal'tseva, 1995)

Margaret was not a ready lover. But where she loved she loved passionately. (Gaskel, 1994)

\begin{abstract}
Allusion
When analyzing the use of phraseological units in discourse, their distribution into two groups is obvious - transformations that violate the perception of the phraseological units and those that preserve it. The peculiarity of the allusion is in the fact that the phenomenon is "on the verge" between the two groups mentioned above, so that the allusion is the most difficult phenomenon to identify (especially when the component of the substantive phraseological unit is clipped). That is why, when identifying the truncated structure it is necessary to study the text, to penetrate into the depth of internal semantic relations (Naciscione, 2001).

The allusion represents the meaning of a linguistic unit in a concentrated form, with the focus on the most important element of information. Since the phraseological unit is not fully manifested in the text, the reader needs to extract it from memory, which is possible only if a listener has a clear understanding of the phraseological meaning. In other words, to restore the basic form, it is necessary to restore the missing components of the unit.

The constancy of the links between the components and the basic form of the unit provides coherence, which is an important element of text interpretation. It is the allusion that demonstrates the power of phraseological coherence, since elements that are not present can be restored only if they are based on the discourse. Moreover, the links of the phraseological unit with the discourse can be implicit, which complicates the procedure of identification of the phenomenon. However, the truncated construction not only conveys a general semantic meaning, but also has its own stylistic meaning. The components, which are only implied, are the part of the text as well as the explicit ones (Naciscione, 2001). For example, the phraseological unit «не солоно хлебавши» is subjected to clipping of the second component, but allusion is identified easily because the unit has a holistic meaning and the component that is left is not used in the contemporary Russian language independently:
\end{abstract}

Тартасов, вернувшись от Ляли не солоно, старался огорчение скрыть (Makanin, 2004)

The most difficult case of identifying the allusion can be observed when only one element of phraseological unit is preserved that can be found in such structures as Adj $+\mathrm{N}$ (adjective + noun $), \mathrm{N}+\mathrm{N}$ (noun + noun $), \mathrm{N}+$ prep $+\mathrm{N}$ (noun + preposition + noun), $\mathrm{V}+$ prep $+\mathrm{N}$ (verb + preposition + noun $)$.

1) The adjective is preserved when phraseological unit with the structure $\operatorname{Adj}+\mathrm{N}$ is clipped. Here the adjective is the semantic center of the structure. 
"Don't you find such a close neighborhood to the mill rather unpleasant at times?" She drew herself up -

"Never. I am not, become so fine as to desire to forget the source of my son's wealth and power." (Gaskell, 1994) - The basic unit is "a fine lady".

In the following example, clipping of the noun is combined with phraseological saturation.

Вена-то не согласна! Ей, загребущей и завидущей, желательно обрести для себя и курляндскую корону. (Пикуль, 1988) - The basic units are «глаза завидущие», «руки загребущие».

2) The noun is preserved when phraseological units with the structures $\mathrm{N}+$ $\mathrm{N}, \mathrm{N}+$ prep $+\mathrm{N}, \mathrm{V}+$ prep $+\mathrm{N}$ are clipped.

Очень уж серьезная она ... И требует, чтобы я непременно рассмешил ее. Тогда, говорит она, можешь свою Маланью по шапке ... а, говорит, вся твоя! (Berezovskiy, 1966) - The basic unit is «дать по шапке».

In the following example, extended metaphor helps to identify the phenomenon:

Listen, I've got to be quick - Tony keeps coming in and shouting about all burdens he has to bear (Frayn, 1999). - The basic unit is "the beast of burdens".

Allusion is easily identified when the proverb is clipped:

Подумаешь! Наш Саша своей ненаглядной по телефону и не такое отмачивает, но его же не волокут в контору в третьем часу ночи. А, ерунда все, обычная профилактика! Слышали звон ... (Mal'tseva, 1995) - The basic unit is «Слышал звон, да не знает, где он».

"Morning. Think we could do with some new chairs in here?"

"Oh, yes, Mr. Wilcox, these are ever so hard."

"I didn't mean your chairs, I mean for visitors."

"Oh ..." They don't know quite how to react. He is still Mr. New Broom, slightly feared. (Gaskell, 1994) - The basic unit is "A new broom sweeps clean".

When using allusions in a dialogue, both interlocutors have to understand the phraseological unit.

\section{Expansion}

Expansion of the phraseological unit (the addition of variable components) traditionally leads to the following types of semantic modification:

1) introduction of additional features of qualifying or quantitative character into the meaning of phraseological unit;

2) concrete definition of the meaning;

3) emotional and expressive intensification (Bershadskaya, 1972).

Expansion of a phraseological unit can be carried out in the following ways:

a) Prepositive expansion (the components are added to the first lexeme of the unit) that leads to actualization of connotative aspect of the meaning. In the following example, the adjective "damned / последний" is added to the unit and actualizes emotional aspect of it.

Приедет ли, всю душу вымотает, приедет ... и или нашпионит, как последний сукин сын или же капризами замучает, и то не так и это не так ...(Булгаков, 1991)

His estate was one of the best managed in the country and he knew how to handle his labor. He was a damned good sort and if he did get on your nerves a little you couldn't help liking him. (Maugham, 1997)

b) Postpositive expansion of the unit (the component is added to the last lexeme) that leads to changes in denotative meaning as well as connotative.

But then at once another mystery opens up: if Antwerp was becoming too hot for Brugel, why on Earth did he think of taking refuge in Brussels, of all cities? It was the 
centre of the Spanish administration. He was jumping out of the frying pan and into the fire - only too literary in all probability. (Frayn, 1999)

После этого распрямился, поднял на старух маленькие, заросшие со всех сторон глаза и возгласил:

-Кур-рва!

- Вот он, святая душа на костылях, - без всякого удивления сказала Дарья. (Rasputin, 1990)

\section{Cleft use}

Cleft use of phraseological unit is a consequence of the occasional complementativity, which is generated to perform a number of additional specialized language functions by a speech or language unit. The phenomenon under study refers to the secondary speech complication that occurs during occasional transformations of a stable combination of words in order to increase their stylistic significance (Kashin, 1989). A.V. Kunin defines the ability of components to enter syntactic relations with various variable elements as one of the main features that characterizes the separate formality of phraseological units (Kunin, 1996). The purpose of cleft use is strengthening the subjective-emotional evaluation, change in evaluation, concrete definition.

In the research, two types of the phenomenon are examined:

a) cleft use - distant location of the components.

b) inserting - inserting of one or two components into the unit.

A popular element to insert in both languages is a pronoun, for example, "he/он".

Но придет время и поймет Петр: сам он себе хозяин на земле, ступать по ней может вольно, говорить громко, дышать полной грудью. (Ivanov, 2017)

Inserting can be accompanied by a change of word order in the English language (inversion), which enhances the emotional color of the statement. For example, phraseological unit "thick skin" in the English language and «добрая душа» in the Russian language:

She knew now that her own nerves were not strong enough, her own skin not thick enough, to bear contact with the insane; she understood the terrible treatment of the insane in the old days. (Galsworthy, 2004)

Плохо ему за барином, объедки да побои, а своруешь - опять бьют. Едина душа была добрая - Потам Сурядов, да и того в солдаты забрили. (Pikul', 1988)

Cleft use (distant location of the elements) is observed in both languages and can be accompanied by revealing of direct sense:

The old boy! He was a darling to have kept that list! A new leaf! She would go at once to Bertie Curfew and get him to turn it over for her! (Galsworthy, 2004) - The basic unit is "to turn a new leaf".

- Ну и кровь у тебя! Горячее кипятка, - говорил он Серафиме.

- Ох, и разбросала бы я семян по земле! - ответила на это однажды она крепких, ядреных...

- С такой же кровью горячей ... (Ivanov, 1999) - The basic unit is «горячая кровь».

Cleft use is a common basis for creating complex cases of instantial use of phraseological units. For example, inserting of a component «вернее» and substitution of the substantive component in the basic unit «козел отпущения» in the Russian language:

Как все мужчины Глеб моментально нашел козла, вернее козу отпущения жену. (Dontsova, 2005)

Demetaphorization of the unit "Balaam's ass" is based on the cleft use in the English language:

They felt as Balaam must have felt when his ass broke into speech. (Maugham, 1979) 


\section{Saturation of the discourse}

Phraseological saturation is the use of two or more phraseological units in the framework of a single discourse. E. Arsent'eva defines two main types of phraseological saturation:

1) Simple -two or more phraseological units are used simultaneously without changing the form.

2) Complex - the units are used in combination with other types of transformation (Arsent'eva et al, 2009).

The following types of saturation are defined taking into account the structure and semantics of the unit:

1) The use of several phraseological units with a synonymous meaning, which leads to strengthening of the connotative aspect of the meaning, in particular, the aspect common to both units.

a) Two phraseological units with analogous structure are used to form saturation. For example, two phraseological units with the structure Adj $+\mathrm{N}$ leads to actualization of the aspect "nobility" which is present in both basic units:

Они считают себя элитой, белой костью и голубой кровью государственной безопасности, их оклады и пайки куда выше наших (Topol', 1996).

b) Two phraseological units with synonymous meaning but different structures are used to form saturation. For example, two phraseological units "sly dog", "hand in glove" are used to form saturation which leads to actualization of the element "slyness":

"You haven't contributed much to the sum of information, Sheppard," said Colonel Garter genially. "You're a sly dog. Hand in glove with the great detective, and a hint as to the way things are going" (Christie, 1980).

In the following example from the Russian language, the sem "experience" is stressed making the discourse expressive.

- ... Да смотри, с оглядкой делай это, чтоб не прознал это ненужный.

- Насчет этого, Матюша, не учи. Меня на мякине не проведешь. Старый воробей (Markov, 2013)

2) Phraseological saturation is formed with the help of two units with antonymous meanings.

Her heart beat with delight. The prospect of spending a whole week with Michael was enchanting. It was just like his good nature to come to the rescue when he knew she was at a loose end (Maugham, 1979).

3) Phraseological saturation is formed by two (or more) phraseological units, which are neither synonyms nor antonyms, but are still in a certain semantic relationship. They can characterize the same object, its neutral or negative features. Here saturation can be used to create an extended metaphor.

Матросов, нагрешивших в загранкомандировках, на родине брали в оборот так, что небо им с овчинку казалось. Седоусые полицейские волки учили молодых: - Tbl дубинки-то о нарушителя не боись сломать, салага, - новую дадут. - В общем, гайки закручивали так, что из-под них с хрустом ползла металлическая стружкка. (Bushkov, 2007) - The basic units are «брать в оборот», «закручивать гайки»

Phraseological saturation serves as a basis for the formation of complex cases of contextual transformations using the following combinations:

1) Saturation and expansion of a phraseological unit.

Implementation of phraseological units here leads to changes of denotative and connotative components of meaning. For example, phraseological units «продать c 
потрохами» and «вызвать на ковер» are subjected to postpositive explication and change in the denotative component of the meaning:

Отоваришься, похорошеешь, займешь место своего непутевого хахаля, который продал тебя с потрохами, с бельем и заколками, будешь сама вызывать его на ковер или в постель. (Mal'tseva, 1995)

The actualization of the connotative aspect of meaning is obvious when the adjectival expander "unbelievable" is used in front of the phraseological unit "pain in the arse", as a result of which the first phraseological unit "turned the other cheek" acquires a negative connotation.

But you couldn't upset Magid with words. He turned the other cheek. Sometimes hundreds of times a day, like a lollipop lady on ecstasy. He had this way of smiling at you, neither wounded nor angry, and then inclining his head ... in a gesture of total forgiveness. He had absolute empathy for everybody, Magid. And it was an unbelievable pain in the arse. (Smith, 2001)

2) Phraseological saturation and substitution.

For example, saturation is formed with the help of transformed phraseological unit "to be in the clouds" with the help of substitution of the first component and verbal phraseological unit "to have something on my mind", which leads to change of original meaning:

"Come on, Sam - get it together. Head in the clouds this evening." - "I'm sorry ... I have a lot on my mind ..." (McEvans, 2007)

Instantial substitution of the components of phraseological unit «куда не кинь всюду клин» leads to creation of the synonym of original phraseological unit. Expressive character of the discourse is created with the help of saturation «между молотом и наковальней»:

«Я попала в жуткое, просто ужасное положение. Очутилась между молотом и наковальней, стою перед камнем с надписью: «Куда ни пойдешь - везде mруба» (Dontsova, 2005).

3) Phraseological saturation and cleft use (inserting)

The combination of saturation and inserting of a phraseological unit in most cases involves an additional contextual transformation, for example, a permutation of a component. In the following passage, the word "Волковой" is inserted with the rearrangement of the components of the phraseological unit «смотреть как волк» and saturation with the help of the unit «Бог шельму метит».

«Волкового не то что зеки и не то что надзиратели - сам начальник лагеря, говорит, боится. Вот Бог шельму метит, фамильицу дал! - иначе, как волк, Волковой не смотрит» (Solzhenitzin, 2004)

A contradictory character of the hero is emphasized by saturation based on two phraseological units-antonyms, of which the second is subjected to rearranging of the components, and inserting of the word "easily":

She had green eyes and sharp bones in her face, and hollow cheeks, and there was something brittle in her reticence that suggested strong will and a temper easily lost. (McEvans, 2007)

When analyzing the complex nature of transformations formed on the basis of saturation of the context, the nature of the coherence of the elements of the discourse is obvious. Phraseological units exert mutual influence both on semantics and on the choice of structural occasional transformation.

\section{Phraseological repetition as a part of complex transformation}

Phraseological repetition is one of the most common means of contextual implementation of phraseological units independently as well as a basis for the formation of a more complex transformation in the discourse. Repetition is an effective way of emotional impact on the recipient, which leads to a significant 
change in the connotative aspect of the meaning. The following types of repetition can be defined in the English and Russian languages:

1) Full (exact) repetition.

In general, accurate repetition is a means of emotional and expressive influence on the reader, so it is right that these aspects of meaning are amplified in the context. For example, the exact repetition of the unit "an old devil" in the English discourse leads to the appearance of a humorous effect, the repetition of the same component in the Russian discourse «сама себе хозяйка» adds a negative connotation to the meaning:

That was indeed my immediate thought: "She's a professional model". And then: "The old devil."

The old devil spoke, after first kissing her hand. (Fowles, 1978)

- Тебе что? Может, и вступлю ... Я сама себе хозяйка.

«Bот, вот ... сама себе хозяйка ...» - зло подумал Бородин. (Ivanov, 2017)

Full repetition is often the basis for the formation of complex cases of transformation such as expanded metaphor or phraseological pun:

a) Full repetition in combination with saturation in English.

For example, full repetition of the phraseological unit "baptism of fire" not only undergoes a double actualization of components, forming a phraseological pun, but is also used in combination with the unit "to turn tail", which is the phraseological saturation of the context.

People always think that not stammering is about jumping in at deep ends, about baptisms of fire. People see stammerers on TV who are forced, one magic day, to go on stage in front of a thousand people and lo and behold a perfect voice flows out .... But that's such utter bollocks. ... The truth is, deep ends cause drowning. Baptism of fire causes third-degree burns. "You can't turn tail at the prospect of public speaking your whole life through, Taylor." (Mitchell, 2007)

b) Full repetition in combination with expansion.

Adding of the phrase «А пастуха съели» to phraseological unit «И волки сыты, и овцы целы» is combined with substitution of verbal component «съели»:

- Хочет скрыть правду, боится оттока вкладчиков, пытается придумать вариант, при котором и волки сыты, и овцы целы. - А пастуха съели, деловито заметила Настя ... - Если волки сыты, а овцы целы, значит, хищники сожрали пастуха, - пояснила Настя (Dontsova, 2005).

The phraseological unit of the English language "golden handshake" is the basis for creating a phraseological pun by double actualization of the nominative component in combination with an exact double repetition and substitution of the nominative component with postpositional extension:

“... my role is a bit higher level than that. In fact I wouldn't be surprised if I don't end up running the business. I'll be able to buy a bigger share with my golden handshake."

"You don't deserve a golden handshake," said Vic. "You deserve a golden kick up the arse. I've a good mind to report you to Stuart Baxter." (Lodge, 1989)

c) Full repetition in combination with contamination.

Contamination of phraseological units "the Devil take the hindmost" and "good works" takes place in combination with full repetition that amplifies the expressiveness of the phrase:

"Do you want a love-song" I said, "or a song of good works?" - "A love-song, a love-song," Stephen said. The Devil takes good works". He said this without smiling. In al the time I was with them I only once saw him smile. - "Good works he will not take, brother, but he will take the rash of speech," the old one said (Unsworth, 1995).

2) Partial repetition of phraseological unit.

For example, inserting of component «ли» is combined with repetition of the first component of the phraseological unit «гады подколодные» in the Russian discourse:

XLinguae, Volume 12, Issue 3, June 2019, ISSN 1337-8384, eISSN 2453-711X 
-Тьфу! - Иван Семенович заходил раздраженно по горнице. - Вот срамщь-то! Ну не гадыли подколодные!

- Ты уж зарился на шубу! - с укором сказала Прасковья Федоровна. - На кой бы уж она?

- Думал я, что они такой свистопляс устроят? Ворье проклятое! Ну не гады ли? (Shukshin, 1991)

Partial phraseological repetition is the basis for the formation of following complex cases of transformation.

a) Partial repetition is the basis for extended metaphor in both languages.

- Как говорят, с париивой овцы хоть шерсти клок.

- От тебя и клока не дождешься, ... (Gromyko, 2004)

"No, I mean attack 'em with low prices," said Wilcox, "take his business away. Tit for tat, only our tit will be a lot more than his tat. He won't know what hit him." (Lodge)

b) Partial repetition in combination with substitution

In the following example, there is a change in the significate -denotative aspect of meaning of the phraseological unit "God knows where" when the pronoun is replaced with "who", since the heroine is sure that the money earned is given to her husband's mistress:

“... Please don't go all hysterical on me because - ..." - "How am I supposed to respond, Micheal? Using our house as security! Then the money gets paid out in tiny parcels to God knows where. Or is it to God knows who?" - "What," Dad went quiet as death, "do you mean by that?" - "I politely ask you what is going on," Mum'd backed off from some sort of brink ... (Mitchell, 2007).

c) Partial repetition is used with saturation, substitution, inserting and expansion in the following English discourse.

"Good," Mr Broadwas speaks as slowly as plants, "for both of you." - "So how long," Isaac pye pushed by, lugging a crate of beers from a van, "we staying on the wagon this time, then, Frank Moran?" - "Ain't getting' off of it." Dean's dad didn't smile back. - "Leopards changing their spots, is it?" - 'I ain't talking 'bout spots, Isaac Pye. Talkin' about drink ..." (Unsworth, 1995).

\section{Conclusions}

The study of functioning of phraseological units, the ways they change reflect wide possibilities of languages. Instantial units are variants of the basic unit, which may exist in certain discourses and are characterized by individual and functional accessory, single use, novelty, expressiveness, ability to change, relationship with the basic unit. The main types of instantial units are substitution, cleft use, allusion, phraseological repetition, saturation and an extended metaphor as a case of complex implementation of phraseological units. All the cases mentioned above are involved in the formation of complex cases of realization of the unit where the meaning is changed according to the intention of the author. In particular, the substitution of a phraseological unit leads to a change in the content, to appearance of additional sems in the meaning of the unit by means of a synonymous and antonymic replacement of the component. The extension of a linguistic unit is carried out with the help of a prepositive or postpositive addition of components, where a prepositional extension leads to a change primarily in the connotative component, and the postpositive one to a change in the denotative component. Inserting of one or more elements often occur in the English and Russian languages, as well as splitting the phraseological units beyond the boundaries of one sentence, creating the effect of intermittent text. To form a complex case of contextual realization of phraseological unit, saturation is the most popular one and can be combined with expansion, substitution, cleft use, truncation, and an expanded metaphor. 


\section{Bibliographic references}

AKSENOV, V. 2001. Moskovskaya Saga. Trilogiya [Moscow Saga]. Moscow: Eksmo-press. (in Russian) ISBN: 9785389131491

ARSENT'EVA, E.F. - ABDULLINA, A.R. - AUPOVA, R.A. - ZHOLOBOVA, A.O. - ZALALEEVA, A.R. - KARIMOVA, S.G. - SAFINA, R.A. - SEMUSHINA, E.Y. 2009. Kontekstual'noe Ispol'zovanie Frazeologicheskikh Edinits [Instantial Use of Phraseological Units]. Kazan: Heter, 68 p.(in Russian) ISBN 978-5-94-113-278-2 shkola: traditsii i sovremennost', vol.1, pp. 115- 116. (in Russian) ISBN: 5-98180047-X

BELYAEVSKAYA, E.G. 1989. Otsenochnaya variativnost' semantiki slov i frazeologizmov v kontekste [The estimated variability of the semantics of words and idioms in context]. In: Angliyskaya frazeologiya v funktsional'nom aspekte, vol. 336, pp. 20-31. (in Russian) ISSN 0130-9742

BEREZOVSKIY, F.A. 1966. Bab'i Tropy [Women's Paths]. Petrozavodsk: Karel'skoe knizhnoe izdatel'stvo. (in Russin) ISBN 5-8334-0019-8

BERSHADSKAYA, F.M. 1972. Formy Upotrebleniya Frazeologicheskoy Edinits v Rechi [Forms of use of phraseological units in speech]. Leningrad: Leningrad State University. (in Russian)

BULGAKOV, M.A. 1991. Master i Margarita [Master and Margaret] In: "Ya Khotel Sluzhit' Narodu ...": Proza. P'yesy. Pis'ma. Obraz pisatelya. Moscow: Pedagogika, pp. 223 - 491. (in Russian) ISBN: 5-7155-0517-8

BUSHKOV, A. 2007. Rasputin. Vystrely iz Proshlogo [Rasputin. Shots from the Past]. Moscow: OLIA Media Group. (in Russian) ISBN: 5-7654-4668-X

CHRISTIE, A. 1980. The mystery of King's Abbot. Moscow: Vyssaya skola.

COE, J. 2008. What a carve up! London: Penguin books. ISBN: 978-0-141-03329-7

DAVLETBAEVA, D.N. 2012. Tipologicheskaya Modeliruemost' Frazeologicheskikh

Edinits (na Materiale Russkogo, Angliyskogo, Frantsuzskogo i Turetskogo Yazykov) [Typological modelling of phraseological units (on the basis of the Russian, English, French and Turkish languages). Cheboksary: Chuvash State University. (in Russian) DONTSOVA, D.A. 2007. Verkhom na «Titanike» [Riding the Titanic]. Moscow: Eksmo. (in Russian) ISBN: 978-5-699-21101-2.

DONTSOVA, D.A. 2005. Tushkanchik v Bigudyakh [Jerboa in Curlers]. Moscow: Eksmo. (in Russian) ISBN: 978-5-699-22748-8

DONTSOVA, D.A. 2005. Rybka po Imeni Zayka [A Fish Called Bunny]. Moscow: Eksmo. (in Russian) ISBN: 978-5-04-091489-0

DONTSOVA, D.A. 2005. Ekstrim na serom volke [Extreme on a Grey Wolf]. Moscow: Eksmo. (in Russian) ISBN978-5-699-84375-6

FOWLES, J. 1978. The Magus. St.Albans: Triad Panther Books. ISBN 0586045120

FRAYN, M. 1999. Headlong. Chatham: Mackays of Chatham. ISBN 0-8050-6285-8

GALSWORTHY, J. A. 2004. A Modern Comedy. Moscow: Manager. ISBN 5-83460217-7

GASKEL, E. 1994. North and South. London: Penguin Books. ISBN 0140620192 (ISBN13: 9780140620191$)$

GROMYKO, O. 2004. Professiya - Ved'ma [Profession - Witch]. Moscow: ARMADA. (in Russia) ISBN: 978-5-9922-0958-2

IVANOV, A.S. 1999. Teni ischezayut $\mathrm{v}$ polden' [Shadows disappear at midday]. Moscow: Eksmo-press. ISBN 5-04-002234-4

IVANOV, A.S. 2017. Povitel'. [Training Bindweed]. Moscow: Veche. ISBN: 987-54444-5648-4

KALENOVA, N.A. 2011. Vnutrennyaya Forma Individual'no-avtorskikh Frazeologicheskikh Edinits (na Materiale Epistolyarnogo Diskursa) [Inner form of individual phraseological units (on the basis of epistolary discourse). In: Frazeologicheskie Chtenie Pamyati Professora V.A. Lebedinskoy. K 70-letiyu so

XLinguae, Volume 12, Issue 3, June 2019, ISSN 1337-8384, eISSN 2453-711X 
Dlya Rozhdeniya. Kurgan: Kurgan University, pp. 141-144. (in Russian) ISBN 978-54217-0071-5

KUNIN, A.B. 1996. Kurs Frazeologii Sovremennogo Angliyskogo Yazyka [Course of Phraseology of Contemporary English Language]. Moscow: Visshaa shkola. (in Russian) ISBN 5-06-002394-X

LODGE, D. 1989. Nice work. London: Penguin books. ISBN. 0140133968 (ISBN13: 9780140133967)

MAKANIN, V.S. 2004. Kavkazskiy Plennyy [Caucasian Captivity]. Moscow: Vargius. (in Russian) ISBN 5-9560-0194-1

MAL'TSEVA, V. 1995. KGB v Smokinge [KGB in Smoking]. Moscow: Terra. (in Russian) ISBN 5-300-00181-3

MARKOV, G.M. 2013. Strogovi. Moscow: Veche. (in Russian) ISBN 987-5-4440927-5

MAUGHAM, W.S. 1997. Theatre. Moscow: Management. ISBN: 5-8346-0031-X

MAUGHAM, W.S. 2004. The Painted Veil. New York: Vintage International. ISBN: 1400034213 (ISBN13:9781400034215)

MCEVANS, I. 2007. Atonement. London: Vintage. ISBN 0-099-52066-4, 978-0-09952065-5

MITCHELL, D. 2007. Black Swan Green. London: Hoddler and Stoughton. ISBN 9780340822807

NACICSIONE, A. 2001. Phraseological Units in Discourse: Towards Applied Stylistics. Riga: Latvian Academy of Culture. ISBN-9984-9519-0-1

PIKUL', 2010. V Slovo i delo. Roman-khronika Vremen Anny Ioanovny. [Word and Deed. The Novel Is a Chronicle of the Times of Anna Ioannovna] Moscow: Veche. (in Russian) ISBN 978-5-9533-5132-4

RASPUTIN, V.G. 1991. Posledniy Srok. Proshchanie s Materoy. Pozhar [Last term. Farewell to Matera. Fire]. Moscow: Sovremennik. ISBN: 5-270-01470-X

SEMUSHINA, E. - SOBOLEVA, N. 2014. Impact of Peculiarities of Context on Instantial Phraseological Units and their Transference into the Language of Translation. In: Phraseology in Multilingual Society. UK: Cambridge Scholars Publishing, pp.239-249. ISBN (10): 1-4438-5584-7, ISBN (13): 978-1-4438-5584-6

SMITH, Z. 2001. White Teeth. London: Penguin books. ISBN: 0140276335 (ISBN13: 9780140276336)

SOLZHENITSIN, A. 2014. Odin den' Ivana Denisovich [One Day of Ivan Denisovich]. Saint-Petersburg: Lenizdat. (in Russian) ISBN 978-5-4453-0484-5

SHUKSHIN, V.M. 1991. Ya Prishel Dat' Vam Volyu [I Came to Give You the Will]. Moscow: Khudozhestvennaya literature. ISBN: 5-280-01685-3

TELIA, V.N. 1996. Russkaya Frazeologiya. Semanticheskiy, Pragmaticheskiy i Lingvokul'turologicheskiy Aspekty [Russian Phraseology. Semantic, Pragmatic and Lingvocultural aspects]. Moscow: Shkola. (in Russian) ISBN 5-88766-047-3

TOLSTAA, T. 2004. Sonia. In: Khrestomatiya dlya sovremennoy russkoy literatury dlya starsheklassnikov i abiturientov. Ekaterinburg: U-Faktoriya, pp. 500-509. (in Russian) ISBN 5-94799-337-6

TOPOL', E, 1996. Sobranie Sochineniy. Krasnyy Gaz. Kremlevskaya Zhena [Collected Works. Red Gas. The Kremlin's Wife] Moscow: AST. (in Russian) ISBN 5-88196-450-0

TRET'AKOVA, I.Y. 2011. Okkazional'nye Frazeologizmy i Kontekst [Instantial Phraseological Units and Context]. In: Yaroslavskiy pedagogicheskiy vestnik. Yaroslavl: Yaroslavl State Pedagogical University, pp.161-163. (in Russian) ISSN 1813-145X.

UNSWORTH, B. 1995. Morality Play. London: Penguin books. ISBN. 0140175741, 9780140175745 . 
Words: 6387

Characters: 41189 (22,88 standard pages)

assoc. prof. Elena Y. Semushina, PhD.

Department of Foreign Languages for Professional Communication

Kazan National Research Technological University

Kazan

Russia

epospelova12@yandex.ru 